International Journal of Instruction e-ISSN: 1308-1470 • www.e-iji.net

Article submission code: 20201105095015

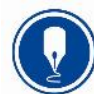

January $2022 \bullet$ Vol.15, No.1

p-ISSN: 1694-609X

pp. 167-184

Received: 05/11/2020

Revision: 11/06/202
Accepted: 07/07/2021

OnlineFirst: 17/10/2021

\title{
The Effectiveness of the TASC, CPS, and DI on Divergent Thinking Skill at Elementary School in Indonesia
}

\section{Tri Murwaningsih}

Universitas Sebelas Maret, Surakarta, Indonesia, murwaningsih_tri@staff.uns.ac.id

\section{Muna Fauziah}

Institut Agama Islam Nahdlatul Ulama Kebumen, Indonesia, munafauziah6@gmail.com

\begin{abstract}
This study aims to determine the effectiveness of using the TASC, CPS, and DI models on divergent thinking skill in thematic learning for fifth-grade public elementary schools in Laweyan District, Surakarta. This research is mixed-method research. The fifth-grade students at a public elementary school in Laweyan District, Surakarta, Indonesia, are the research subjects. The subjects of this study were 271 elementary school students. The techniques used were tests, questionnaires, observations, and interviews. The TASC and CPS models were used as experimental models (treatment classes), while the DI models were used as models applied in the control class. The data validity technique of this research used three ways, namely content validity; construct validity; and data triangulation (methods and sources). Data analysis was carried out in two ways. First, the quantitative analysis was done through the analysis prerequisite test, hypothesis testing, and multiple comparison tests. Second, qualitative analysis utilized interactive analysis (data reduction, data presentation, and drawing conclusions). The results revealed that the TASC learning model is more effective in applying thematic learning than the CPS and DI models when viewed from the adversity quotient. The TASC model helps students maximize divergent thinking skills compared to other models, student activity in the CPS model has not been maximized, especially in divergent thinking skill, meanwhile student activity in applying the DI model is very boring and students are very passive. In short, the results of this study can be used as a reference for academics (teachers, lecturers, or future researchers) to determine innovative learning models that can maximize students' higher order thinking skills.
\end{abstract}

Keywords: divergent thinking skill, adversity quotient, learning models, mixed method research, elementary school

\section{INTRODUCTION}

The $21^{\text {st }}$-century education has discussed various thinking skills like creative, critical, reflective, and communication skills (Cortes et al., 2019). Everyone must have these

Citation: Murwaningsih, T., \& Fauziah, M. (2022). The effectiveness of the TASC, CPS, and DI on divergent thinking skill at elementary school in Indonesia. International Journal of Instruction, 15(1), 167-184. https://doi.org/10.29333/iji.2022.15110a 
skills in the 5.0 era. Sometime before, Indonesia was still in the 4.0 era. However, for now, it has more developed to 5.0, especially in advanced countries, such as Japan, China, Singapore, and others. Indonesia also must participate in keeping abreast of the times, both in terms of education and technology. In line with these developments, Indonesia must be prepared to change old habits towards modern directions, such as technology, economy, or education aspects (Fahmi et al., 2016). In the aspect of education, teachers in Indonesia must be prepared to compete with foreign countries. Students are expected to have the skill in 21 st-century education to pass the global competition and take advantage of all opportunities (Suryandari et al., 2018). Therefore, teachers must be able to create innovative learning and improve students' skills to compete at the next school level (Ersoy \& Baser, 2014).

Part of the creative thinking skill is divergent and insightful thinking (Subali \& Mariyam, 2016). Creative signifies the skill of creating new ideas or developing existing ideas into items that have valuable value (Madore et al., 2015). A creative person cannot be separated from the role of divergent thinking. Divergent thinking becomes an ability that dominates the creative brain (Yi et al., 2015). Students with the ability to think divergent will show attitudes and behaviours beyond reason, such as the frequency of asking more. Besides, he is more flexible and has a different way when he solves problems. When in class, students like experimental activities or practical actions. With these activities, they have the opportunity to mobilize all of their ideas during the completion of the practicum. Convergent thinking is not enough because they only think straight or narrow without combining the environment or learning experience (Simon \& Bock, 2016). It is certainly not justified because the 5.0 era requires people who can read situations and opportunities. These criteria are only owned by people who think divergent. Therefore, the teacher has a role in changing the students' mindset from those who want to be cared for, be independent students, hard workers, and read opportunities.

The importance of divergent thinking skills is in line with the Minister of Education and Culture Regulation No. 37 of 2018. This regulation contains the fulfilment of students' basic needs to develop their abilities in the digital age. Education should be able to add and integrate informatics content into basic competencies, both in the curriculum framework or curriculum structure, from elementary to secondary education.

Study results related to the divergent thinking skills in several countries still show unsatisfactory results. Teachers still ignored the students' characteristics in teaching, so they appeared to have no special readiness during teach (Halder et al., 2017). Wu \& Albanese (2013) has also conducted research in Taiwan about the difficulties of developing divergent thinking skills. His research results concluded that teachers in Taiwan had experienced difficulty in developing this skill. The teacher reasoned that their school still used the old curriculum. In line with the research, Sharma \& Dhingra (2018) also stated the same thing. They expressed teachers' difficulty in teaching divergent thinking skills in elementary schools.

Further, Adnan et al. (2019) explained that the primary school age was not the right age to teach students divergent thinking skills. They would rather play than think about hard 
things. It was also confirmed by Zabelina \& Ganis (2018) that students found it difficult to participate in learning because they preferred to have light discussions and rarely carried out activities with many stages or processes.

This behaviour should not be left without problem-solving. The teachers and educational institutions' role is vital. Broader problems may occur again. Local teachers will find it increasingly difficult to compete with foreign teachers from abroad who teach in Indonesia. They may feel depressed if they cannot adjust to the times. Traditional learning will continue to occur because the teacher feels sufficient with the current learning conditions. Even more comprehensive impact is that Indonesia's ranking in the competence at the international level, such as PISA, would continue to decline and always ranked in the top ten to five categories from the bottom of several countries participating in PISA (OECD, 2015).

Based on these conditions' analysis, a learning model is needed that supports students to be good thinkers and can provide many alternative answers to a problem. Action that can be taken is to apply the Thinking Actively in a Social Context (TASC) model. The TASC model is a series of lessons that provide analytical teaching in contextual problem-solving (West, 2008). According to Wallace et al. (2012), the TASC model consists of some learning syntax: (1) gather/organize, (2) identify, (3) generate, (4) decide, (5) implement, (6) communicate, (7) evaluate, and (8) learn from experience. The TASC model has four main elements: the ability to think (thinking), students' active participation (actively), social cooperation (social), and learning that is relevant to students' experience (context). The four elements provide a problem-based learning experience so that it is expected to develop students' divergent thinking skills.

The use of the Creative Problem Solving (CPS) model is also an alternative for implementing problem-based learning. The CPS learning model is a variation of problem-solving based learning through more creative systematic techniques. The CPS learning model's syntax consists of (1) clarifying the problem, (2) expressing opinions, (3) evaluation and selection, and (4) implementation (Sari et al., 2018). CPS suggests the proficiency of various skill types such as creative and critical so that students can generate and analyze their ideas to their full potential (Hajiyakhchali, 2013). Kanchanachayaa \& Shinasharkey (2015) argued that the CPS technique implementation was preferred and enjoyed by educators in Thailand. Learning became different, and students were interested in discussing it. Other studies' results also uncovered that the CPS model could help students overcome barriers to learning, facilitate their abilities, be more creative, active, and enjoy participating (Wang, 2019).

Another innovative model that can be applied is the Direct Instruction (DI) model. Buchori, et al. (2017) argue that the DI model is a model that is carried out face-to-face in class with an instructor from the teacher to initiate discussion activities, and has a special focus on textbooks and notes. The direct instruction model according to Moore (Marzuki, 2016) has several steps, namely: (1) orientation; (2) presentation; (3) structural practice; (4) guided practice; and (5) independent practice. According to Helling, et al. (2016), the direct instruction model has an influence on the learning achievement of students because of the large amount of material that must be delivered 
directly by the teacher. The results of his research explain that broad material will be more effective if it is delivered directly.

The learning process is not the only way that can affect divergent thinking skills. Adversity quotient or response-ability also has the potential to develop thinking skills. Adversity quotient is a struggle to solve the difficulties faced. Adversity quotient is divided into three categories: climber, camper, and quitter (Stolz, 2000). Climber type of adversity quotient has an unyielding attitude, confidence, taking advantage of opportunities, hard work, and study hard (Firmansyah et al., 2016). Camper type adversity quotient is individuals who do not want to take high risks. They are quite satisfied with the results that have been obtained, although they are not at the maximum result yet. They also have a semi conceptual thought process in solving problems (Verma et al., 2017). Quitter type of adversity quotient gives up easily and without effort because they consider the problem a difficult thing (Hutagalung \& Muchtar, 2018). Thus, this study aims to determine the effectiveness of using the TASC, CPS, and DI models in the thematic learning of fifth-grade public elementary schools in Laweyan District, Surakarta.

\section{Review of Literature}

\section{Divergent thinking skill}

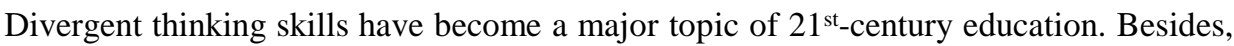
divergent thinking is the skill to find varied answers or solutions to a problem (Acar et al., 2019). The variation answer is based on several considerations to solve the problem. Meyer \& Lederman (2015) affirmed that divergent thinking is recognized as a critical component of creativity and can be understood as a type of thinking with many disorganized ideas generated by open tasks. The idea is based on several considerations that can solve the problem.

Students with divergent thinking skills would demonstrate different behavioural signs from other students. Simon \& Bock (2016) stated that divergent thinking's characteristics are usually novelty, flexible, unique, not self-limiting, and sensitive to the environment. The novelty characteristic is defined as not being the same as the existing ones, even though it is idea development. Several studies have discussed divergent thinking skills' assessment. Divergent thinking skill was confirmed to have several indicators, consisting of four components (1) fluency, (2) flexibility, (3) originality, (4) and elaboration (Acar \& Runco, 2014).

\section{TASC learning model}

The TASC model was first developed by Belle Wallace. This learning concept is different from the model in general. Wallace et al. (2012) explained that the TASC model is a problem-solving framework that provides students' structure independently or in small groups. Besides, students can take a topic, investigation, or research project indepth and as broad as they choose and use all the information on the appropriate website. The TASC program's emphasis on learning lies in the problem-solving process carried out by students, but regardless of the structure or knowledge skills they have (Ball \& Handerson, 2009). 
The TASC model comprises some learning syntax, namely (1) finding out what is already known with the teacher's guidance; (2) identifying what must be done; (3) generalizing the methods that will be used by each group; (4) determining the best idea to solve the problem; (5) implementing the ideas that have been agreed upon to solve the problem; (6) communicating ideas; (7) evaluating the results of implementing the idea, both the product produced and the problem-solving process; (8) studying all the processes and discussions students have discussed together (Wallace et al., 2012

\section{CPS learning model}

According to Apino \& Retnawati (2016), the CPS model is seen as a form of variation in problem-based learning. The aspect developed in this model is creativity. Student learning activities are increasingly well patterned through this model to be more motivated to learn. The CPS model has a role in developing divergent and convergent thinking; however, the most crucial aspect is the ability to generate many innovative (divergent) ideas (Chen \& Chen, 2019). The CPS model's syntax contains (1) problem clarification, whose activities include explaining the problem posed and ensuring students understand the solution to the problem; (2) opinion gathering, which frees students to argue and respond to problems; (3) evaluation and selection, which evaluates by sorting out strategies according to the problem, both supporting and rejecting each idea; (4) implementation, which applies a predetermined strategy to find a problemsolving point and develop it (Cropley, 2015).

\section{DI learning model}

Joyce, Well, \& Calhoun (2016) explain that the direct instruction model is used to refer to the teaching model which consists of explaining new concepts or skills to students which then asks students to test their understanding by practicing under teacher guidance. According to Marzuki (2016), direct instruction learning consists of five steps, namely orientation, presentation, structured practice, guided practice, and independent practice. Bryant, et al. (Ayaz \& Sekerci, 2015) said that the direct model has more teacher and student meeting intensity so that they will have good closeness and communication.

\section{Thematic learning}

Thematic learning is one of the approaches in the 2013 curriculum. Thematic learning is learning that uses themes in linking several subjects so that it can provide meaningful experiences to students (Puspitasari, Nuryanti, \& Rede, 2015). This learning has the following characteristics: (1) oriented towards student activity, (2) forming meaningful understanding and learning, (3) direct learning experiences, and (4) prioritizing process over student learning outcomes (Narti et al., 2016) ).

\section{METHOD}

\section{Research Design}

This study used a mixed-method approach. Mixed methods research is a research design based on assumptions like the inquiry method (Creswell, 2014). This method provides assumptions in showing direction or providing guidance on collecting, analyzing data, and combining quantitative and qualitative approaches through several phases of the 
research process. Mixed research methods focus on data collection and analysis and combine quantitative and qualitative data, both in single studies and series studies.

Quantitative research in the form of numerical data that must be processed and carried out by statistical tests of the data was as follows: (1) data, (2) describing each variable, (3) checking or testing requirements, (4) testing hypotheses, and (5) interpreting. The quantitative research type used was a quasi-experimental design. This type was conducted through treatment. It aimed to find the influence of certain variables on other variables accompanied by control.

Qualitative research used as support was symbolic interactionism type. Symbolic interactionism is centered on two basic things: humans as the main act and humans acting on the meaning given by something. This research has fulfilled the first basic requirement of symbolic interaction research, namely the existence of human action. This action was in the form of using a learning model in the learning process.

\section{Population and Sample}

The population is a generalization area consisting of subjects and objects with specific characteristics and determined by the researcher to study and draw conclusions. This study was conducted in nine public elementary schools in Laweyan District, Surakarta City, at the beginning of the first semester of the 2019/2020 academic year. This research population was fifth-grade elementary school students in Laweyan District, Surakarta City, and Central of Java. The selected population had a large enough number of schools, so that the researchers only used a representative sample of the population. Although only selecting samples, the conclusions obtained would be generalized to the entire population. The sample of this research was 270 of fifth-grade elementary school students. The technique of determining the sample was using cluster random sampling techniques concerning representatives of population characteristics.

The sampling technique in this study was the stratified cluster random sampling technique. Stratified random sampling is a sampling technique considering a level (strata) in population elements. Population elements are divided into several levels (stratification) based on the characters attached to them. In stratified random sampling, population elements are grouped at certain levels to sampling evenly at all levels, and the sample representing the character of all heterogeneous population elements.

\section{Research Variables}

The variables of this study are divided into two, namely the dependent variable and the independent variable. The dependent variable is the response variable or criterion that is assumed to be influenced by the independent variable (Creswell, 2014). The dependent variable in this research is divergent thinking ability. Meanwhile, the independent variable is the variable that affects the dependent variable and the variable being treated (Creswell, 2014). In this study, the independent variable is a learning model consisting of the TASC, CPS, and DI learning models.

\section{Data Collection Tools}

The data validity technique used content validity and construct. The construct validity was done by comparing the researchers' conceptual definition with the original author's 
original definition (Ortiz, 2009). Expert evaluators became evaluators of construct validation. The construct validity was used to test the instrument, so it could be said to be valid according to the construction. Construction means that instrument writing rules are made correctly so that the instrument is not ambiguous or has multiple interpretations when given to the respondents. Content validity was employed to test an instrument so that the instrument could be said to be valid according to its contents. Content is the material, indicating that a measuring instrument can reveal the concept contents or variable to be measured. Content validation was carried out several times until the instrument could be said of feasible for empirical testing. The instrument has content validity if it measures specific objectives in line with the material or content given. Meanwhile, the instrument has construct validity if the instrument items measure every aspect of thinking according to instructional objectives.

The construct validity results showed some improvements in each instrument. On the instrument of divergent thinking skill, it can be concluded that the correction of some experts asked for improvement in the choice of words from the sentence questions, suggested to use easily understood question words by elementary school students, and sentence errors of several test items. Meanwhile, the questionnaire instrument's construct validity results lay in the editorial errors of the questionnaire sentences and the sentence structure. After the two instruments were repaired, the experts assessed that the divergent thinking skill test instrument and the adversity quotient questionnaire could be used to test the instrument further.

The test trial results were analyzed with the product-moment correlation formula. The test validity processing produced data on the correlation coefficient values of all test items of $\geq 0.30$. It means that test items were feasible and could be used for data collection. The questionnaire trial results were calculated for the internal consistency of each statement item. Fifty statements were calculated for the internal consistency with an internal consistency index value of $r_{x y} \geq 0.30$, while ten other statements obtained less than .30. If the internal consistency index results are $\geq 0.30$, then the questionnaire statement item can be used. The reliability results of the two instruments also showed reliable data. The test instrument got a reliability result of 0.851 for eight test items, while the questionnaire instrument was 0.945 for 50 valid items. The difficulty level calculation results in all items having a moderate level of difficulty with a difficulty index of $0.30 \leq \mathrm{P} \leq 0.70$. Calculation of distinguishing power test for divergent thinking skills resulted in eight items having good distinguishing power with a distinguishing power index of $\geq 0.30$.

\section{Data Collection Technique}

This study utilized to test and non-test instruments to collect data in accordance with its objectives. The test instrument was used to test the effectiveness of using TASC, CPS, and DI models on divergent thinking skill. This instrument contained 10 test items in an essay form. The material employed contained divergent thinking skill in elementary schools. Non-test technical instruments used included observation and interviews. Observations were carried out independently using validated observation sheets. Data collection techniques used was tests and questionnaires. The divergent thinking skills' 
measurement employed test instruments. The type of test was an open description test. The number of test questions was eight questions. Adversity quotient measurement utilized a questionnaire instrument. The number of the statements was 60 items. The questionnaire instrument scale used four scales (1-4). The categories included strongly agree (SA), agree (A), disagree (DA), and strongly disagree (SDA). Preparation of test instruments and questionnaires adjusted the indicators on each variable.

\section{Research Procedure}

This research was carried out in several steps. The stages are as follows: (1) conducting a preliminary study to determine the initial research problems; (2) analyzing the results of the preliminary study; (3) compiling research instruments; (4) validating the instruments to the experts; (5) testing the research instrument on students outside the research sample; (6) calculating the results of the validity and reliability of the instrument; (7) testing the pre-research instrument; (8) carry out treatment in the experimental class and control class; (9) carry out testing after treatment (post-test); (10) perform the calculation of the descriptive analysis test, the prerequisite test, the balance test and the multiple comparison test; (11) analyzing the research results qualitatively; and (12) compiling research results in the form of research reports.

\section{Data Analysis}

The data analysis technique in this study was carried out in two stages. Test data were analyzed using Microsoft excel, while non-test results were analyzed using interactive analysis by Miles and Huberman. Quantitative data analysis was divided based on the pretest and posttest results. Quantitative analysis was performed by calculating the normality test, homogeneity test, balance test, hypothesis test, and multiple comparison tests.

In quantitative analysis, the test instrument was tested before and after the implementation of treatment. The terms used are pre-test and post-test. The purpose of implementing the pre-test is to determine the initial ability of students (before being given treatment) in each class, both the experimental class and the control class. Meanwhile, the purpose of the post-test is to compare the results before the application of the model with the results of students' scores after the TASC, CPS, and DI models are applied. The two results will be compared, whether the results are improved or not.

The normality test was conducted to determine whether the data to be analyzed is normally distributed or not. Researchers employed the Liliefors method with a significance level of 0.05 .

Table 1

Summary of population normality test results on student posttest data

\begin{tabular}{llllll}
\hline Model & Amount & Lobs & Ltable & Test Decision & Conclusion \\
\hline TASC & 90 & 0,0692 & 0,0934 & $\mathrm{H}_{0}$ was accepted & Normally distributed \\
\hline CPS & 91 & 0,0871 & 0,0928 & $\mathrm{H}_{0}$ was accepted & Normally distributed \\
\hline DI & 89 & 0,0843 & 0,0939 & $\mathrm{H}_{0}$ was accepted & Normally distributed \\
\hline
\end{tabular}

A summary of the normality test calculation results based on the adversity quotient can be seen in Table 2 . 
Table 2

Summary of normality test results based on aq

\begin{tabular}{llllll}
\hline Adversity Quotient & Amount & $\mathrm{L}_{\mathrm{obs}}$ & $\mathrm{L}_{\text {table }}$ & Test Decision & Conclusion \\
\hline Climbers & 90 & 0,0843 & 0,0934 & $\mathrm{H}_{0}$ was accpeted & Normally distributed \\
\hline Campers & 94 & 0,0843 & 0,0913 & $\mathrm{H}_{0}$ was accepted & Normally distributed \\
\hline Quitters & 86 & 0,0947 & 0,0955 & $\mathrm{H}_{0}$ was accpeted & Normally distributed \\
\hline
\end{tabular}

Based on the normality test results in Tables 1 and 2, it can be seen that Lobs in each model and AQ were not included in the critical area. Therefore, it can be concluded that the data for each group, both based on the learning model and the AQ, came from a normally distributed population.

The homogeneity test aimed to prove that the data came from a population with not much diversity and whether the data used was homogeneous. The homogeneity test employed the Bartlett test.

Table 3

Summary of homogeneity test results

\begin{tabular}{lllll}
\hline Group & $X^{2}$ obs & $X^{2}$ table & Critical Area & Test Decision \\
\hline Learning model & 3,7715 & 5,991 & $X^{2}{ }_{\text {obs }}<X^{2}$ table & H$_{0}$ was accepted \\
\hline AQ & 5,575 & 5,991 & $X^{2}{ }_{\text {obs }}<X^{2}$ table & Ho was accepted \\
\hline
\end{tabular}

Table 3 proves that the population variances were the same (homogeneous). The value of $X^{2}{ }_{\text {obs }}$ for the group based on the learning model did not exceed the value of $X^{2}$ table and the value of $\mathcal{X}^{2}$ obs based on $\mathrm{AQ}$ did not exceed the value of $\mathcal{X}^{2}$ table so that $\mathrm{H}_{0}$ was accepted.

The technique utilized to analyze the research data inferential was by using the analysis technique of two ways with unequal cell variances (Two-Ways ANOVA). Multiple comparisons are a follow-up to the variance analysis. If the variance analysis results indicate that the hypothesis $\mathrm{H}_{0}$ is rejected, it is necessary to carry out further tests using the Scheffe method.

The interactive analysis was carried out continuously until the data were saturated. Data reduction took place throughout the study. These activities included summarizing, selecting main points, and focusing on important things. The next step was to present the data. Data were presented in tabular and narrative form, which allowed conclusions and action taken. After the data were well organized, a tentative conclusion was made.

\section{FINDINGS}

\section{Descriptive Statistical Test}

This research begins with the application of the TASC, CPD, and DI learning models. Then, the researcher continued the calculation of the results of the students' divergent thinking ability tests. The test results were analyzed by calculating the post-test results, analysis of variance, and multiple comparisons. The posttest divergent thinking skills analysis results are displayed in the following table. 
Table 4

Students' divergent thinking skills posttest results

\begin{tabular}{lllllll}
\hline AQ Level & $\begin{array}{l}\text { TASC } \\
\text { Model }\end{array}$ & $\begin{array}{l}\text { Mean score of } \\
\text { post-tests }\end{array}$ & $\begin{array}{l}\text { CPS } \\
\text { Model }\end{array}$ & $\begin{array}{l}\text { Mean score } \\
\text { of post-tests }\end{array}$ & $\begin{array}{l}\text { DI } \\
\text { Model }\end{array}$ & $\begin{array}{l}\text { Mean score } \\
\text { of post-tests }\end{array}$ \\
\hline Climber & 29 & 88,21 & 31 & 80,61 & 30 & 71,40 \\
\hline Camper & 37 & 76,38 & 30 & 67,83 & 27 & 60,07 \\
\hline Quitter & 24 & 68,08 & 30 & 60,17 & 32 & 58,78 \\
\hline
\end{tabular}

Based on Table 4, the TASC learning model had a higher mean score than the CPS and DI learning models. The CPS learning model had a higher mean score than the DI learning model. Hypothesis testing was analyzed through two-way analysis variance (ANOVA) with unequal cell variances. The two-way ANOVA analysis results based on the research data are shown in the following table.

Table 5

Summary of two-way anova with unequal cell variances

\begin{tabular}{llllll}
\hline Source & Critical Area & $\mathrm{RK}$ & Fobs & Ftable & Test decision \\
\hline Learning model (A) & 2 & 4468,84 & 62,21 & 3,03 & Rejected \\
\hline AQ (B) & 2 & 7273,10 & 101,24 & 3,03 & Rejected \\
\hline Interaction (AB) & 4 & 173,69 & 2,42 & 2,40 & Rejected \\
\hline Error & 261 & 71,84 & & & \\
\hline Total & 269 & & & & \\
\hline
\end{tabular}

Information:

Critical Area : The critical area of all data sizes

$\mathrm{F}$

: The $\mathrm{F}$ value obtained from the table

RK : Mean Squared

Test Decision : $\mathrm{H}_{0 \mathrm{~A}}$ was rejected because $\mathrm{F}_{\mathrm{A}}$ entered a critical area

$\mathrm{H}_{0 \mathrm{~B}}$ was rejected because $\mathrm{F}_{\mathrm{B}}$ entered a critical area

$\mathrm{H}_{0 \mathrm{AB}}$ was rejected because $\mathrm{F}_{\mathrm{AB}}$ entered a critical area

Based on two-way ANOVA with unequal cell variance test results, it can be seen that the score of $\mathrm{F}_{\mathrm{obs}}$ exceeded the score of $\mathrm{F}_{\text {table }}$ so that $\mathrm{H}_{0 \mathrm{~A}}$ was rejected. The score of $\mathrm{F}_{\mathrm{obs}}$ exceeded the score of $\mathrm{F}_{\text {table, }}$, so that $\mathrm{H}_{\mathrm{OB}}$ was rejected. Besides, $\mathrm{F}_{\mathrm{obs}}$ exceeded $\mathrm{F}_{\text {table }}$ so that $\mathrm{H}_{0 \mathrm{AB}}$ was rejected. Thus, it can be concluded that: (1) the learning model is proven to be effective against divergent thinking skills, (2) adversity quotient affects divergent thinking skills, and (3) there is an interaction between learning models (TASC, CPS, and DI) and the adversity quotient against divergent thinking skills.

Therefore, it was necessary to do a follow-up test post-ANOVA to answer the research hypothesis. The multiple comparative analysis test was carried out because the existence of a learning model and adversity quotient proved effective against divergent thinking skills, as well as the interaction between learning models and adversity quotient on divergent thinking skills. Furthermore, it is calculated in each column and row to find out more details about which model is better among the three models (TASC, CPS, and DI) and to find out which type of adversity quotient is more dominant (climber, camper, and quitter). Table 6 below is a summary of the results of the calculation of the mean comparison test between rows. 
Table 6

Multiple comparison results of means between rows

\begin{tabular}{llll}
\hline Comparison Between Rows $(\mathrm{A})$ & $\mathrm{F}_{\text {obs }}$ & $\mathrm{F}_{\text {table }}$ & Test decision \\
\hline TASC VS CPS & 40,499 & 6,06 & $\mathrm{H}_{0}$ was rejected \\
\hline CPS VS DI & 23,452 & 6,06 & $\mathrm{H}_{0}$ was rejected \\
\hline TASC VS DI & 124,506 & 6,06 & $\mathrm{H}_{0}$ was rejected \\
\hline
\end{tabular}

Table 6 verifies that $\mathrm{H}_{0}$ was rejected or there was a significant effect of learning models on students' divergent thinking skills. In summary, we can conclude three things: (1) the TASC model is more effective than the CPS and DI models, and (2) the CPS model is more effective than the DI model.

The calculation of the $\mathrm{H}_{0 \mathrm{~B}}$ variance analysis test is rejected, so further tests are needed to find out which type AQ students are better. The summary of the results of these calculations is presented in table 7 below.

Table 7

Multiple comparison results of means between columns

\begin{tabular}{lllll}
\hline $\begin{array}{l}\text { Comparison Between } \\
\text { Columns (B) }\end{array}$ & $\mathrm{F}_{\text {obs }}$ & $\mathrm{F}_{\text {table }}$ & Test decision & Test decision \\
\hline Climber VS Camper & 91,827 & 6,06 & $\mathrm{H}_{0}$ was rejected & $\mathrm{H}_{0}$ was rejected \\
\hline Camper VS Quitter & 20,680 & 6,06 & $\mathrm{H}_{0}$ was rejected & $\mathrm{H}_{0}$ was rejected \\
\hline Climber VS Quitter & 113,85 & 6,06 & $\mathrm{H}_{0}$ was rejected & $\mathrm{H}_{0}$ was rejected \\
\hline
\end{tabular}

Table 7 confirms that the adversity quotient affected students' divergent thinking skills. In detail, it can be indicated that the climber type students are better than the camper and quitter types, while the camper type students are better than the quitter type.

Furthermore, the calculation of the two-way analysis of variance test results in the $\mathrm{H}_{0 \mathrm{AB}}$ being rejected. That is, there is an interaction between the learning model and AQ on divergent thinking skills. Thus, it is necessary to calculate further tests after the analysis of variance. The following is a summary of the calculation of the fiber comparison test between cells in the same column.

Table 8

Multiple comparison results of means between cells in the same column

\begin{tabular}{lllll}
\hline \multirow{2}{*}{ Climbers } & Comparison between cells in the same column & $\mathrm{F}_{\text {obs }}$ & $\mathrm{F}_{\text {table }}$ & Test decision \\
\cline { 2 - 5 } & TASC VS CPS & 12,028 & 15,76 & $\mathrm{H}_{0}$ was accepted \\
\cline { 2 - 5 } & CPS VS DI & 18,013 & 15,76 & $\mathrm{H}_{0}$ was rejected \\
\cline { 2 - 5 } Campers & TASC VS DI & 57,981 & 15,76 & $\mathrm{H}_{0}$ was rejected \\
\cline { 2 - 5 } & TASC VS CPS & 16,839 & 15,76 & $\mathrm{H}_{0}$ was rejected \\
\cline { 2 - 5 } & CPS VS DI & 11,909 & 15,76 & $\mathrm{H}_{0}$ was accepted \\
\hline \multirow{2}{*}{ Quitters } & TASC VS DI & 57,761 & 15,76 & $\mathrm{H}_{0}$ was rejected \\
\cline { 2 - 5 } & TASC VS CPS VS DI & 11,632 & 15,76 & $\mathrm{H}_{0}$ was accepted \\
\cline { 2 - 5 } & TASC VS DI & 0,413 & 15,76 & $\mathrm{H}_{0}$ was accepted \\
\hline
\end{tabular}

From Table 8, it can be interpreted that students with AQ climber type in each learning model did not affect divergent thinking skills. However, students with the camper type have been presented to influence each learning model's divergent thinking skills. 
Therefore, it can be concluded that: (1) the TASC model is as effective as the CPS model but more effective than the DI model, while the CPS model is more effective than the DI model on the climber type AQ; (2) the TASC model is more effective than the CPS and DI models, while the CPS model is as effective as the DI model on the camper type AQ; and (3) the TASC model is as effective as the CPS model, the CPS model is as effective as the DI model, but the TASC model is better than the DI model.

Then, the following is a summary of the results of the calculation of the mean comparison test between cells in the same row in table 9 .

Table 9

Multiple comparison results of means between cells in the same row

\begin{tabular}{lllll}
\hline & Comparison between cells in the same row & $\mathrm{F}_{\text {obs }}$ & $\mathrm{F}_{\text {table }}$ & Test decision \\
\hline \multirow{2}{*}{ TASC } & Climber VS Camper & 31,664 & 15,76 & $\mathrm{H}_{0}$ was rejected \\
\cline { 2 - 5 } & Camper VS Quitter & 13,943 & 15,76 & $\mathrm{H}_{0}$ was accepted \\
\cline { 2 - 5 } & Climber VS Quitter & 74,027 & 15,76 & $\mathrm{H}_{0}$ was rejected \\
\hline \multirow{2}{*}{ CPS } & Climber VS Camper & 30,660 & 15,76 & $\mathrm{H}_{0}$ was rejected \\
\cline { 2 - 5 } & Camper VS Quitter & 12,273 & 15,76 & $\mathrm{H}_{0}$ was accepted \\
\cline { 2 - 5 } & Climber VS Quitter & 88,721 & 15,76 & $\mathrm{H}_{0}$ was rejected \\
\hline \multirow{2}{*}{ DI } & Climber VS Camper & 25,375 & 15,76 & $\mathrm{H}_{0}$ was rejected \\
\cline { 2 - 5 } & Camper VS Quitter & 0,340 & 15,76 & $\mathrm{H}_{0}$ was accepted \\
\cline { 2 - 5 } & Climber VS Quitter & 34,321 & 15,76 & $\mathrm{H}_{0}$ was rejected \\
\hline
\end{tabular}

Table 9 provides data that the climber-type AQ performs better than the camper and quitter, while the camper-type AQ is as good as the quitter-type on the TASC, CPS, and DI models. Meanwhile, students with AQ types of campers and quitter had no impact on divergent thinking skills.

\section{Participatory Observation Results}

Qualitative data were collected through observation during learning. Qualitative data contained divergent thinking skill's role during the learning process. The posttest was conducted to find out the differences in divergent thinking skill after implementing the learning model. The observation results reported data that the divergent thinking skill behavior in the TASC, CPS, and DI models groups had different learning processes. Students with climber AQ had good divergent thinking competencies. Students demonstrated active questioning, provided input, had good leadership and were sensitive to the environment.

On the other hand, students with AQ camper simply followed the teacher and other students' instructions during group work. They did not dare to ask questions directly or respond to teachers. Students were more willing to ask their friends first. However, the students were good enough to condition themselves when in a new place. Meanwhile, students with the AQ quitter type were still not able to present themselves. They lacked the confidence to ask questions or respond to teachers. Students had not been able to demonstrate a sensitive attitude to the environment. 


\section{Interview Results}

Moreover, the researchers also conducted interviews with teachers after the posttest implementation. The interview results were taken from the fifth-grade teachers. The following Table 10 is a summary of the interview data.

Table 10

Summary of teacher interview results

\begin{tabular}{|c|c|c|c|}
\hline Results & Approved b & Not approved by & Explanation \\
\hline $\begin{array}{l}\text { The learning process had } \\
\text { several difficulties. }\end{array}$ & $\begin{array}{l}100 \% \\
\text { respondent }\end{array}$ & respondent & $\begin{array}{l}\text { Teachers often experienced difficulties in the learning } \\
\text { process, both in terms of delivery methods, material } \\
\text { content, and even inappropriate module books. }\end{array}$ \\
\hline $\begin{array}{l}\text { The class atmosphere } \\
\text { depended on the class's } \\
\text { character. }\end{array}$ & $\begin{array}{l}100 \% \\
\text { respondent }\end{array}$ & $\begin{array}{l}0 \% \\
\text { respondent }\end{array}$ & $\begin{array}{l}\text { The class atmosphere formed when learning was very } \\
\text { dependent on the students' characteristics in the class so } \\
\text { that the treatment in each class could not be equated. }\end{array}$ \\
\hline $\begin{array}{l}\text { Learning required } \\
\text { various models. }\end{array}$ & $\begin{array}{l}100 \% \\
\text { respondent }\end{array}$ & $\begin{array}{l}0 \% \\
\text { respondent }\end{array}$ & $\begin{array}{l}\text { Various learning models were selected and adapted to the } \\
\text { learning material. }\end{array}$ \\
\hline $\begin{array}{l}\text { The use of the TASC and } \\
\text { CPS models was } \\
\text { beneficial during } \\
\text { learning. }\end{array}$ & $\begin{array}{l}100 \% \\
\text { respondent }\end{array}$ & $\begin{array}{l}0 \% \\
\text { respondent }\end{array}$ & $\begin{array}{l}\text { Learning through the TASC and CPS models made } \\
\text { students more active and willing to work together. } \\
\text { Students showed a happy attitude, and the teacher was } \\
\text { easy to manage the class swiftly. }\end{array}$ \\
\hline $\begin{array}{l}\text { The TASC and CPS } \\
\text { models attracted more } \\
\text { students' attention. }\end{array}$ & $\begin{array}{l}100 \% \\
\text { respondent }\end{array}$ & $\begin{array}{l}0 \% \\
\text { respondent }\end{array}$ & $\begin{array}{l}\text { The TASC and CPS models made students more interested } \\
\text { in the learning process because they had to be carried out } \\
\text { through in-depth investigation and experimentation. }\end{array}$ \\
\hline
\end{tabular}

\section{DISCUSSION}

Based on the research results, learning model affects divergent thinking skills when viewed from the adversity quotient. There are several points generated on proving the effectiveness of the learning model on divergent thinking skills. First, the TASC learning model was superior to other models in each AQ category. The TASC learning model's syntax was more profound. Moreover, there were activities with a direct practice that students had to do. Practical activities would give a distinct impression to students. They would be more active in participating in learning. This behavior is in accordance with the TASC learning model's characteristics, one of which is emphasizing students to become active thinkers. Lakey (2009) found that the TASC model application provided better results on the students' thinking skills. He further explained that students had more opportunities to collaborate, experiment, and reflect on themselves to be better. This research is relevant to research conducted by Mutaqy et al. (2019). Their research results indicated that the learning model also affected problemsolving abilities. Problem-solving is, of course, still related to the ability to think because the problem-solving process will go through a divergent and convergent thinking process.

Compared with the CPS and DI learning models, both models had a simpler syntax. As stated by Nazzal (2015), this model was still limited to opinion gathering through small and large group discussions. Unlike the DI model, this model did not emphasize student activeness. Ayaz \& Sekerci's (2015) study results found that teachers explained more in front of the class so that students did not have the opportunity to develop their creativity. This fact is also supported by the research results, which proved that the DI learning 
model did not have a different effect on the students' thinking ability. Besides, Temel (2014) ascertained that the DI learning model did not affect students' problem-solving abilities and perceptions. Based on the results above, teachers need to optimize the available learning time properly through exercises and open lessons with other teachers.

Second, the research is shown from the dominance of the AQ type in each model. The results showed that students with type AQ climbers had better performance than other AQ types. These results can be confirmed because students with AQ climber type did have a strong motivation to succeed. This statement is in accordance with the theory presented by Stolz (2007), which stated that climbers know that many benefits can be taken after experiencing their hard work, so they will take advantage of every opportunity they find to achieve the best success. These results are also in accordance with the research results by Ardiansyah \& Asikin (2018), which identified that students with AQ climber type had a strong belief to solve problems and get the best performance. Students with a climber type AQ had the courage to face problems. The ability to respond to the things around him influenced his thinking power. This study's results are also relevant to Pangma et al. (2009) opinion that students with AQ climber type had high learning motivation, could understand problems well and could think creatively.

Some of the students with AQ climber type's characteristics can be seen that they needed a learning model in line with their thinking power. The CPS learning model was said to be relevant to students' thinking ability with AQ climber type. The CPS learning model supported students in arguing actively, discussing each other, respecting other people's opinions, and learning to implement their opinions. Thus, students would be more challenged to follow learning well. It is in line with Samson's (2015) opinion. His research results provided data that the CPS learning model supported students to develop more. The CPS model was also seen as a model that emphasizes students' creativity (Apino \& Retnawati, 2016).

Overall, the results exposed that in the DI learning model, the AQ climber type had the skill to think divergent better than the others. This study's results are relevant to research conducted by Dewanto et al. (2019). Their research resulted in data that students with AQ climber type had better learning achievement than students with AQ camper and quitter type, as well as students with AQ camper type also gave better results than students with AQ quitter type. Looking at the previous studies' results, it appears that this study's results contradict their results.

However, this research was not always carried out without experiencing obstacles. During the observation process, the researchers found another fact that the TASC learning model provided high critical power and learning motivation to students, especially students with AQ type climbers and campers. Unfortunately, the teacher has not fully accommodated students' critical abilities. The teacher more often chose active students to be asked, asked for presentations, or invited to collaborate. Therefore, teachers should pay attention to the slightest thing that students do for their success. 


\section{CONCLUSION}

Based on the results of the study it can be concluded that: (1) the TASC learning model is more effective in applying thematic learning than the CPS and DI models when viewed from the adversity quotient; (2) Climber type students who learn to use the TASC model are very dominant in the mastery of divergent thinking skills than AQ type or other types of models; and (3) the application of the TASC, CPS, and DI models can facilitate students to be active and learning is not boring. Then, the researchers gave suggestions to several parties. Since classroom management has not been appropriately implemented, especially in regulating learning time and student conditioning, teachers can do things such as (1) practice managing time independently so that learning can be optimized according to the specified time; (2) teachers should provide their own physical and socio-emotional conditions so that students feel comfortable and safe during learning; (3) teachers should pay attention to existing factors in students and environmental factors; (4) the teacher can invite students to discuss if the class conditions are not responsive. Meanwhile, the results of this study can also be a reference or idea for future researchers. The idea taken can be in the form of selecting a similar learning model to be developed or more in-depth analysis with a different learning approach from this research.

\section{REFERENCES}

Acar, S., \& Runco, M. A. (2014). Assessing associative distance among ideas elicited by tests of divergent thinking. Creativity Research Journal, 26(2), 229-238.

Acar, S., Alabbasi, A. M. A., Runco, M. A., \& Beketayev, K. (2019). Latency as a predictor of originality in divergent thinking. Thinking Skills and Creativity, 33, 1-10.

Adnan, A., Beaty, R., Silvia, P., Spreng, R. N., \& Turner, G. R. (2019). Creative aging: Functional brain networks associated with divergent thinking in older and younger adults. Neurobiology of Aging, 75(1), 150-158.

Apino, E., \& Retnawati, H. (2016). Creative problem solving to improve students' higher order thinking skills in mathematics instructions. Proceeding of 3rd International Conference on Research, Implementation and Education of Mathematics and Science, hlm. 339-346. Yogyakarta: Universitas Negeri Yogyakarta.

Ardiansyah, A. S., Junaedi., \& Asikin, M. (2018). Student's creative thinking skill and belief in mathematics in setting challenge-based learning viewed by adversity quotient. Unnes Journal of Mathematics Education Research, 7(1), 61-70.

Ayaz, M. F., \& Sekerci, H. (2015). The effects of the constructivist learning approach on student's academic achievement: a meta-analysis study. TOJET: The Turkish Online Journal of Educational Technology, 14(4), 143-156.

Ball, S., \& Henderson, K. (2009). Using the TASC wheel to challenge more able children in an inclusive environment. Gifted Education International, 25, 56-99.

Buchori, A., Setyosari, P., Dasna, I.W., Ulfa, S., Degeng, I.N.S., \& Sa'dijah, C. (2017). Effectiveness of direct instruction learning strategy assisted by mobile augmented reality 
and achievement motivation on students cognitive learning results. Asian Social Science, 13(9), 137-144.

Chen, H. L., \& Chen, Y. J. (2019). Influence of a creative problem-solving approach on college students' creativity and its relation with team cohesion. Journal of Research in Education Sciences, 64(3), 169-201.

Cortes, R. A., Weinberger, A. B., Daker, R. J., \& Adam, E. (2019). Re-examining prominent measures of divergent and convergent creativity. Behavioral Sciences, 27(1), 90-93.

Creswell, J. W. (2014). Research design: Qualitative, quantitative, and mixed methods approaches 4th edition. USA: Sage Publication.

Cropley, D. H. (2015). Creativity in engineering: novel solutions to complex problems. London: Academic Press.

Dewanto, M. D., Budiyono, \& Pratiwi, H. (2019). The experiment of TAPPS, TSTS, and DL learning models viewed through adversity quotient in mathematics learning achievement. IOP Conf. Series: Journal of Physics: Conf. Series, 243(1), 1-10.

Ersoy, E., \& Baser, N. (2014). The effects of problem-based learning method in higher education on creative thinking. Procedia - Social and Behavioral Sciences, 116, 3494-3498.

Fahmi, F. Z., Koster, S., \& Dijk, J. V. (2016). The location of creative industries in a developing country: The case of Indonesia. Cities, 59, 66-79.

Firmansyah, A. H., Djatmika, E. T., \& Hermawan, A. (2016). The effect of adversity quotient and entrepreneurial self-efficacy on entrepreneurial intention through entrepreneurial attitude. IOSR Journal of Business and Management, 18(5), 45-55.

Hajiyakhchali, A. (2013). The effects of creative problem solving process training on academic well-being of shahid chamran university students. Procedia - Social and Behavioral Sciences, 84, 549-552.

Halder, S., Roy, A., \& Chakraborty, P. K. (2017). The influence of personality traits on the information-seeking behaviour of students. Malaysian Journal of Library \& Information Science, 15(1), 41-53.

Helling, J., Mclaughlin, T.F., Weber, K.P., Dolliver, M.P., \& Slotvig, P. (2016). The effects of direct instruction procedures with a place value chart and model-lead-test error correction procedure to teach regrouping with three-digit subtraction accuracy: A case study disabilities. International Journal of English and Education, 15(1), 391-402.

Hutagalung, B., \& Muchtar, Y. C. (2018). The adversity quotient (Control, Origin \& Ownership, Reach, and Endurance) and its relationship toward entrepreneurial intention: A study on the student in the Faculty of Economics \& Business Universitas Sumatera Utara. Atlantis Press, 46, 409-413.

Joyce, B., Weil, M., \& Calhoun, E. (2016). Model of teaching. Yogyakarta: Pustaka Pelajar. 
Kanchanachaya, N., \& Shinasharkey, T. (2015). A study on interactions between anonymous and non-anonymous pre-service teachers in blended learning using creative problem solving technique to enhance pre-service teachers' ability in professional practices. Procedia - Social and Behavioral Sciences, 174, 2401 - 2406.

Lakey, J. (2009). Purposeful, creative problem solving. Gifted Educational International, 25(1), 60-70.

Madore, K. P., Addis, D. R., \& Schacter, D. L. (2015). Creativity and memory: Effects of an episodic-specificity induction on divergent thinking. Psychological Science, 26(9), 1461-1468.

Marzuki, I. (2016). Escalating ability to write papers: to make use of direct instruction. International journal of Learning, Teaching and Educational Research, 15(2), 106-116.

Meyer, A.A. \& Lederman, N.G. (2015). Creative cognition in secondary science: An exploration of divergent thinking in science among adolescents. International Journal of Science Education, 37(10), 1547-1563.

Minister of Education and Culture Regulation. (2018). Minister of education and culture regulation number 37 of 2018 concerning competencies and basic competencies of learning in the 2013 curriculum on basic education and middle education. Jakarta, Indonesia: Minister of Education and Culture Regulation.

Mutaqy, R. M., Nasution., \& Purnomo, N. H. (2019). Effects of TASC learning model (Thinking Actively in a Social Context) on ability problem-solving in natural resource management materials. The Indonesia Journal of Social Studies, 2(1), 1-8.

Narti, Y., Setyosari, P., Degeng, I. N. S., \& Dwiyogo, W. D. (2016). Thematic Learning Implementation in Elementary School (Phenomenology Studies in Pamotan SDN 01 and 01 Majangtengah Dampit Malang). International Journal of Science and Research (IJSR), 5(11), 1849-1855. https://doi.org/10.21275/ART20163223.

Nazzal, L. J. (2015). Engineering creativity: Differences in creative problem solving stage across domains. University of Connecticut Graduate School: UCONN Library.

OECD. (2015). Pisa results in focus 2015. Washington: OECD Publishing.

Ortiz, D. (2009). Research design: Qualitative, quantitative, and mixed methods approaches (3rd Ed.). Thousand Oaks, California: Sage Publication, Inc.

Pangma, R., Tayraukham, S., \& Nuangchalerm, P. (2009). Causal factors influencing adversity quotient of twelfth-grade and third-year vocational students. Journal of Social Sciences, 5(4), 466-470.

Puspitasari, I.D., Nuryanti, S., \& Rede, A. (2015). Promoting of Thematic-based Integrated Science Learning on the junior. Journal of Education and Practice, 6(20), 97-102.

Samson, P. L. (2015). Fostering student engagement: creative problem solving in small group facilitations. Collected Essat on Learning and Teaching, 8, 153-164. 
Sari, D. M., Ikhsan, M., Abidin, Z. (2018). The development of learning instruments using the creative problem-solving learning model to improve students' creative thinking skills in mathematics. IOP Conf. Series: Journal of Physics: Conf. Series, 1-5.

Sharma, N., \& Dhingra, R. (2018). Assessment of opportunities available to school children for the development of divergent thinking ability. International Journal of Current Advanced Research, 7(9), 15301-15307.

Simon, A., \& Bock, O. (2016). Influence of divergent and convergent thinking on visuomotor adaptation in young and older adults. Human Movement Science, 46, 23-29.

Siphai, S. (2015). Influences of moral, emotional and adversity quotient on good citizenship of rajabhat university's students in the northeast of Thailand. Educational Research and Reviews, 10(7), 2413-2421.

Subali, B., \& Mariyam, S. (2016). The divergent thinking of basic skills of sciences process skills of life aspects on natural sciences subject in Indonesian elementary school students. Asia-Pacific Forum on Science Learning and Teaching, 17(1), 23.

Suryandari, K. C., Sajidan, Rahardjo, S. B., Praetyo, Z. K., \& Fatimah, S. (2018). Project-based science learning and pre-service teachers' science literacy skills and creative thinking. Cakrawala Pendidikan, XXXVII(3), 345-355.

Temel, S. (2014). The effects of problem-based learning on pre-service teachers' critical thinking dispositions and perceptions of problem-solving ability. South African Journal of Education, 34(1), 1-20.

Verma, S., Aggarwal, A., \& Bansal, H. (2017). The relationship between Emotional Intelligence (EQ) and Adversity Quotient (AQ). IOSR Journal of Business and Management (IOSR-JBM), 19(1), 49-53.

Wallace, B., Bernardelli, A., Molyneux, C., \& Farrell, C. (2012). TASC: Thinking actively in a social context: A universal problem-solving process: A powerful tool to promote differentiated learning experiences. Gifted Education International, 28(1), 58-83.

Wang, H. C. (2019). Fostering learner creativity in the English 12 classroom: application of the creative problem-solving model. Thinking Skill and Creativity, 31/10, 58-69. West, H. (2008). A study of the impact of using the TASC wheel on children's involvement in their own learning. Gifted Education International, 24(2), 297-304.

Wu, J., \& Albanese, D. L. (2013). Wellsprings and streams of education - the Taiwan experience. Educational Psychology: An International Journal of Experimental Educational Psychology, 33(5), 561-581.

Yi, X., Plucker, J. A., \& Guo, J. (2015). Modeling influences on divergent thinking and artistic creativity. Thinking Skills and Creativity, 16, 62-68.

Zabelina, D. L., \& Ganis, G. (2018). Creativity and cognitive control: Behavioral and ERP evidence that divergent thinking, but not real-life creative achievement, relates to better cognitive control. Neuropsychologia, 118(1), 20-28. 